\title{
UDC 329.11
}

\section{Galyna Kuts}

Doctor of political sciences, professor, professor of the department of political science, sociology and cultural science of the Kharkiv National Pedagogical University by G. S. Scovoroda,

e-mail: galyna.kuts@i.ua

\section{CLASSICAL CONSERVATISM AS A POLITICAL IDEOLOGY: DOMINANT IDEAS AND HEURISTIC POTENTIAL}

\begin{abstract}
The purpose of this article is to identify the dominant ideas of the discourse of classical conservatism as a political ideology, which are applicable in the modern political and ideological process. The article presents the consideration of the ideology of conservatism in comparison with other classical ideologies (liberalism and socialism) and highlighted the key features of conservatism.

The methodological basis of the article was the set of scientific and special methods of political science. The research methodology is based, in particular, on such scientific principles as the unity of historical and logical, the ascent from the Abstract to the concrete, objectivity, consistency, principles of analysis and synthesis and the like. Using system method the analysis of conservatism as a whole system with a complex structure. In the context of the comparative method, we carried out the selection of the dominant ideas of the discourse of conservatism. In particular, using comparativistic approach highlighted the basic criteria of the distinction between conservatism and other classical political ideologies (I.Wallerstein, K.Manheim, F.A. von Hayek, etc. ).

In the ideological field of conservatism - despite the powerful Arsenal of fundamental principles - ably offers a conceptual «recipes» that are composed of ideas, which are able to optimally adapt on the specific historical and political realities. That is, even today, the ideas of conservatism inherent in heuristic potential. In particular, the ideas of the evolutionary interpretation of social progress; the sharp rejection of the radical actions and extremism; awareness of the importance of the irrational components in public life and lack of desire to fix it by administrative measures, etc. in addition, it is understood that private property is inviolable. Conservatism attaches great importance to the spontaneously established institutions (for example, language, morality, customs, values, etc. ). Also very interesting are the ideas about what you should not place undue worry problem the required leverage limit managerial power. According to conservatives, more importance should be given to entities that will use them.
\end{abstract}

Keywords: conservatism, classical political ideologies, dominant ideas, liberalism, socialism. 


\section{УДК 329.11}

\section{Г. М. Куц}

Доктор політичних наук, професор кафедри політології, соціології та культурології, Харківський національний педагогічний університет імені Г. С. Сковороди,

e-mail: galyna.kuts@i.ua

\section{КОНСЕРВАТИЗМ ЯК КЛАСИЧНА ПОЛІТИЧНА ІДЕОЛОГІЯ: ДОМІНАНТНІ ІДЕЇ ТА ЕВРИСТИЧНИЙ ПОТЕНЦІАЛ}

\section{Резюме}

Мета статті полягає у виявленні домінантних ідей дискурсу консерватизму як класичної політичної ідеології, які застосовні у сучасному політико-ідеологічному процесі. У статті здійснено розгляд ідеології консерватизму у порівнянні з іншими класичними ідеологіями (лібералізм та соціалізм) та виокремлено ключові ознаки консерватизму.

Методологічною основою статті стала сукупність загальнонаукових та спеціальних методів політичної науки. У контексті компаративного методу здійснено виокремлення домінантних ідей дискурсу консерватизму.

Виокремлено домінантні ідеї консерватизму, яким притаманний евристичний потенціал: ідеї еволюційної інтерпретації суспільного поступу; неприйняття різких радикальних заходів та екстремізму; усвідомлення важливості ірраціональної компоненти в державному житті та відсутність прагнень усунути ії адміністративними заходами та ін.

Ключові слова: консерватизм; класичні політичні ідеології; домінантні ідеї; лібералізм; соціалізм.

\section{1. Ветуп}

Консерватизм - одна із трьох класичних політичних ідеологій поряд із лібералізмом та соціалізмом. Термін консерватизм (лат. conservo - зберігаю, охороняю) введений у науковий обіг французьким мислителем Ф. Шатобріаном у кінці XVIII ст. Підгрунтям консервативної ідеології, теоретичні постулати якої викристалізувалися у другій половині XVIII ст.-на початку XIX ст., стала доктрина торі. Фундатором теорії консерватизму вважається Е. Берк, основні ідеї якого викладені в праці «Роздуми про революцію у Франції та про суперечки в деяких лондонських товариствах щодо цієї події, що містяться в листі, який передбачався бути відправленим деякому благородному пану в Париж» $(1790$ р. ). Значний внесок у розробку теорії консерватизму здійснили Ж. де Местр, Л. де Бональд та ін.

Власне кажучи, політичні ідеології можна розглядати як певний орієнтир, що координує та спрямовує суспільне буття. На думку Д. Кеттлера «ідеології є прикладами символічно навантажених вірувань і понять, за допомогою яких існує, інтерпретується й оцінюється світ; їх призначенням $є$ формування, актуалізація, спрямування, структурування й виправдання певних способів чи напрямів одних видів діяльності і засудження інших» [1, с. 141].

Вважається, що виникнення консерватизму, як й інших класичних політичних ідеологій, зумовлене синтезом різноманітних ідей (філософські ідеї Просвітництва, політичні революції, руйнування феодальних відносин, промислово-технологічне переозброєння, секуляризація суспільних форм буття тощо), що в сукупності дало могутній поштовх для його становлення.

У цілому, ідеологія консерватизму викликала підвищену увагу в різні історичні періоди, зокрема, у контексті вибору найбільш оптимальної моделі устрою держави чи стратегії іії розвитку. Це актуалізує виявлення домінантних ідей дискурсу консерватизму, які були б адекватні сучасним суспільно-політичним реаліям. 


\section{2. Методи дослідження}

У методологічному плані стаття зорієнтована на використання досліджень 3 різних напрямків політико-ідеологічного знання. Сукупність загальнонаукових та спеціальних методів політичної науки стала методологічною основою статті, що, у цілому, забезпечило комплексний підхід до проблеми виявлення евристичного потенціалу консерватизму в сучасному політичному процесі. Методологія дослідження грунтується, зокрема, на таких загальнонаукових принципах як єдність історичного та логічного, сходження від абстрактного до конкретного, об'єктивність, системність, на принципах аналізу і синтезу тощо. За допомогою системного методу здійснено аналіз консерватизму як цілісної системи зі складною структурою. У контексті компаративного методу здійснено виокремлення домінантних ідей дискурсу консерватизму. Зокрема, за допомогою компаративістського підходу виокремлено базові критерії відмінностей між консерватизмом та іншими класичними політичними ідеологіями (I. Валлерстайн, К. Манхейм, Ф. А. фон Хайєк та ін. ).

\section{3. Результати}

У політичній науці загальноприйнятим є виділення трьох типів класичних політичних ідеологій: консерватизму, лібералізму та соціалізму. Пріоритетність однієї з ідеологій, або поєднання якихось двох із них періодично призводили до переважання тієї чи іншої ідеологічної проблематики, детермінуючи своєрідність специфіки політичного простору. Слід зауважити, що окремі світоглядні позиції і консерватизму, і лібералізму, і соціалізму періодично як протиставлялися, так і співпадали.

Консерватизм та лібералізм, вийшовши в епоху Нового часу майже одночасно на історичну арену, відстоювали антагоністичні позиції щодо напрямів суспільного розвитку. Згодом до їхньої дискусії доєднався соціалізм. Сутність тієї чи іншої ідеології найпростіше виявити через аналіз ключових категорій, пріоритетних для кожної з класичних ідеологічних доктрин. На наш погляд, базовою ідеологемою для консерватизму виступає категорія «порядок», для лібералізму - «свобода», для соціалізму-«справедливість». Це зовсім не означає, що, скажімо, поняття свободи менш важливе для консерватизму, чи поняття порядку або справедливості не має значення для лібералізму. Кожна з ідеологій вкладає свій специфічний зміст у розуміння цих категорій. Як зазначав Р. Арон, «справжнім західняком є той, хто цілком схвалює в нашій цивілізації лише свободу, яка дозволяє критикувати цю цивілізацію і дає шанс ії поліпшити» $[2$, с. 60]. Разом з тим, змістовне наповнення концепту свободи суттєво відрізняється у ліберальній та соціалістичній інтерпретації. Якщо для ліберала поняття свободи стосується насамперед створення умов для розширення спектру індивідуальних можливостей, то для соціаліста поняття свободи експлікується найчастіше у контексті зрівнювання таких можливостей. Так само поняття порядку по-різному інтерпретується соціалізмом і консерватизмом. Для консерватора порядок постає «як результат постійної уваги з боку авторитету, якому дозволяється у зв'язку 3 цим діяти за конкретними обставинами і не підпорядковуватись якомусь жорсткому правилу» [3, с.69], тоді як для соціаліста порядок $є$ результатом всемогутнього конструктивного раціонального планування.

Достатньо цікавою видається початкова самолегітимізація всіх трьох ідеологій. Як зазначав К. Манхейм, «вожді консервативних партій вважали себе виразниками народу, ліберали-виразниками духу часу, соціалісти і комуністи-пролетарської класової свідомості» [4, с. 121-122]. Таке позиціювання не в останню чергу зумовлене тогочасним соціокультурним фоном, зокрема, ставленням до новацій та змін. На думку І. Валлерстайна, виникнення політичних ідеологій саме в епоху Нового часу пов'язане з формуванням позитивного ставлення до ідеї змін, причому, цьому сприяла Французька революція. Французька революція змінює світ-систему, з'являється нова геокультура. Зміщення акцентів у політичному дискурсі на позитивне сприйняття ідеї змін витіснило ідею пріоритетності політичної стабільності на задній план. Саме реакцією на цю ідею стала поява трьох ідеологічних доктрин - консерватизму, лі- 
бералізму та соціалізму [5, с. 76-77], кожна з яких дає свою відповідь щодо ідеї «нормальності» змін. Якщо ідеологія консерватизму стала першою (причому негативною) реакцією на цю ідею, то з боку лібералізму та соціалізму спостерігалося позитивне ставлення до змін. Відмінність полягала в розумінні характеру процесу змін. В ідеології лібералізму, яка вийшла на історичну арену другою (після консерватизму) вважається, що змінам має бути притаманний реформаторський характер, вони повинні бути поступовими та раціонально осмисленими. В ідеології соціалізму, навпаки, вважається, що зміни мають бути революційними.

Недовіра до новацій стала однісю із засадничих рис консерватизму, тоді як лібералізм і соціалізм позитивно налаштовані на динаміку змін. Ця недовіра до змін в ідеології консерватизму була певним чином породжена ідеєю, що «марновірство, діючи заодно з мудрістю, укутує ії відчуттям, яке придає їй стійкість» [6, с. 164]. Разом з тим, стосовно консерватизму слід зазначити, що він не заперечує зміни загалом, просто консерватор покладається на вищу мудрість чи авторитет, який спостерігатиме за всіма змінами, ретельно упорядковуючи їх. Як зазначав фундатор теорії консерватизму Е. Берк: «я ні в якому разі не виключав би зміни; але коли б навіть щось змінював, то для того, щоб зберегти» [7, с. 473].

Щодо способу пояснення світу ліберал займає серединну позицію між соціалістом та консерватором. Він «настільки ж далекий від грубого раціоналізму соціаліста, який хоче перебудувати усі соціальні інституції згідно із взірцем, приписаним його індивідуальним розумом, як і від містицизму, де консерватор частенько шукає прихистку» [3, с. 74]. Разом з тим, орієнтація на раціональне впорядкування світу поєднує лібералів та соціалістів. Втім, якщо соціалісти ототожнюють раціональність із плануванням, то для лібералів така позиція $є$ неприйнятною. Раціоналізм ліберального світосприйняття припускає вбудовування в обставини (певний конформізм) та визнання і сприйняття спонтанних утворень (систем цінностей, моралі тощо). Певним чином такі погляди зближують лібералізм з консерватизмом. Але, якщо ліберали виступають за збереження і подальшу адаптацію до змінюваних соціокультурних умов тих спонтанних утворень, які зумовили виживання та успіх певної групи, то консерваторам притаманна ірраціоналістична інтенція (яка межує з містицизмом) на цілковите збереження існуючих систем цінностей чи моральних догм.

Консерватизм (як і лібералізм) надає великого значення спонтанно сформованим інститутам (приміром, мова, мораль, звичаї, цінності тощо). Але це захоплення з боку консерваторів стосується найчастіше тих спонтанних інституцій, які з'явилися в минулому. Консерватизм із підозрою та недовірою відноситься до тих спонтанних утворень, які лише визрівають (приміром, явища моди).

Разом $з$ тим, вельми важливим для консерватизму є той факт, що він усвідомлює важливість «значення ірраціонального середовища в житті держави і не прагне усунути його адміністративними заходами» [4, с. 104$]$.

Усі три класичні ідеологічні доктрини розділяють позицію стосовно того, що в історії існують зв'язки, які піддаються розумінню та осмисленню. Але, якщо ліберали і соціалісти дотримувались точки зору, що такі зв'язки піддаються повній раціоналізації, то консерватори прагнули пізнати історичну цілісність методом споглядання та морфології [4, с. 117].

Для консерватизму та лібералізму спільною виглядає позиція щодо необхідності обмеження втручання держави в економіку та превалювання вільного ринку [8, с. 14]. Зосередження акцентів на означеній проблематиці зумовлює важливість ідеї конкуренції, яка є вельми актуальною для консерватизму й лібералізму та неприпустимою для соціалізму.

Стосовно обмеження втручання держави в економіку слід зазначити, що на думку Ф. А. фон Хайєка, «подібно до соціаліста, консерватор менше переймається проблемою необхідних важелів обмеження управлінської влади, аніж тим, хто їх застосовуватиме» [3, с.70]. Консерватор глибоко впевнений, що коли управління належить порядним людям, його не варто достатньо жорстко обмежувати. 
Позиція щодо обмеження державного втручання в економіку зумовлює вибір ринкової економіки як лібералізмом, так і консерватизмом [9]. Базовим на разі виступає припущення, що саморегулятивні сили вільного ринку створять механізми адаптації до нових економічних умов.

В економічній сфері консерватори вітають вільний ринок, хоча в окремих галузях вони й виступають за протекціонізм, що споріднює їх із соціалістами. Але не лише ця позиція їх споріднює. Консерватор так само, як і соціаліст, «вважає себе уповноваженим нав'язувати іншим людям цінності, які він схвалює» [3, с. 70]. У цьому контексті зазначимо, що для ліберала його власні ціннісні пріоритети не $є$ вагомою підставою для того, щоб змушувати інших їх поділяти. Відповідно, ліберали вважають, що релігійні чи моральні ідеали неприпустимо нав'язувати іншим, тоді як консерватори і соціалісти переважно дотримуються протилежної точки зору.

Стосовно позиції консерватизму щодо проблеми пріоритетності колективістських чи індивідуалістських цінностей слід зазначити, що «зазвичай в індустріальній сфері консерватори чинять опір колективістським та директивним заходам, і тут ліберал часто знаходить в них спільників» [3, с. 72]. Але певна кореляція націоналізму із консерватизмом «частенько прокладає місток від консерватизму до колективізму» [3, с. 74].

Як ліберали, так і консерватори вважають, що приватна власність $є$ недоторканною.

На думку К. Манхейма, диференціація історичного часу залежить від тієї утопії, яку поділяє конкретна соціальна група [4, с. 179]. Консервативне сприйняття часу орієнтоване в минуле, оскільки вважається, що саме в минулому були створені всі варті уваги цінності та інституції.

Відносно психологічної мотивації прихильників консерватизму слід зазначити, що ії підгрунтям виступають морально-етичні імперативи. Вважається, що «історія містить божественний задум, і обов'язок людини полягає у дотриманні Богом даних незмінних моральних законів» $[10$, с. 21$]$.

\section{4. Висновки}

Таким чином, крізь призму компаративістського підходу виявлено визначальні характеристики консерватизму як класичної політичної ідеології на основі таких основоположних критеріїв відмінностей: ключова ідеологема; ставлення до змін, новацій; спосіб пояснення світу; характер суспільного розвитку; ставлення до спонтанно сформованих інституцій; відношення до необхідності обмеження впливу держави; економічні пріоритети; ставлення до приватної власності; співвідношення «індивідуальне/колективне»; сприйняття історичного часу; психологічна мотивація.

У цілому, недовіра до новацій стала однією із засадничих рис консерватизму. Разом із тим, консерватизм не заперечує зміни загалом, просто консерватор покладається на вищу мудрість (Бог) чи авторитет, який спостерігатиме за всіма змінами, ретельно упорядковуючи їх. Консерватизм характеризується опозиційністю щодо рішучих змін, неприйняттям різких радикальних заходів, екстремізму. Для консерватизму притаманна орієнтація на збереження традиційних цінностей (національних, релігійних, цивілізаційних), устоїв, вірувань, недовіра до абстрактних теорій тощо. У розумінні характеру суспільного розвитку консерватизм дотримується еволюційної інтерпретації суспільного поступу. Консерватизм надає вагомого значення спонтанно сформованим інститутам (приміром, мова, мораль, звичаї, цінності тощо). Але це захоплення з боку консерваторів стосується найчастіше тих спонтанних інституцій, які з'явилися в минулому. Консерватизм із підозрою та недовірою ставиться до тих спонтанних утворень, які лише визрівають. Разом із тим, вельми важливою для консерватизму є та обставина, що він, усвідомлюючи важливість ірраціональної компоненти в державному житті, не прагне усунути iii адміністративними заходами.

В ідеології консерватизму вважається, що приватна власність є недоторканною. Позиція щодо обмеження державного втручання в економіку зумовлює вибір ринкової економіки як консерватизмом, так і лібералізмом. В економіці консерватизм вітає вільний ринок, хоча в окремих галузях він виступає за протекціонізм, що споріднює його з соціалізмом. Консерватор менше переймається проблемою необхідних важелів обмеження управлінської влади, аніж тим, хто їх 
буде застосовувати. Консерватор глибоко впевнений, що коли управління належить порядним людям, його не варто достатньо жорстко обмежувати. Щодо проблеми пріоритетності колективістських чи індивідуалістських цінностей у консерватизмі вважається, що колективом мусить правити еліта суспільства.

У консерватизмі так само, як і в соціалізмі пріоритетною $є$ позиція, що у сфері моральних переконань допустимим $є$ примус у нав'язуванні іншим людям цінностей, які схвалюються в рамках ідеології консерватизму. Держава для консерватизму-це не лише джерело та захисник законів, але й захисник моралі.

Слід зазначити, що окремі домінантні ідеї дискурсу консерватизму, будучи застосовними щодо сучасного політико-ідеологічного процесу, мають певний евристичний потенціал. Зокрема, це ідеї еволюційної інтерпретації суспільного поступу; неприйняття різких радикальних заходів та екстремізму; усвідомлення важливості ірраціональної компоненти в державному житті та відсутність прагнень усунути іiі адміністративними заходами. Крім того, це розуміння, що приватна власність $є$ недоторканною. Консерватизм надає великого значення спонтанно сформованим інститутам (приміром, мова, мораль, звичаї, цінності тощо). Також доволі цікавими видаються ідеї стосовно того, що не варто надмірно перейматися проблемою необхідних важелів обмеження управлінської влади. На думку консерваторів більше значення слід придавати суб'єктам, які їх будуть застосовувати. Консерватор глибоко впевнений, що коли управління належить порядним людям, його не варто достатньо жорстко обмежувати.

\section{5. Список літератури:}

1. Кеттлер Д. Ідеологія / Девід Кеттлер // Енциклопедія політичної думки; [пер. $з$ англ. Н. Лисюк, С. Альошкіної, І. Підлуської / редколег.: К. Сігов, В. Скуратівський, Л. Фінберг]. - К.: Дух і Літера, 2000.-472 с.—С. 141-143.

2. Арон Р. Опій інтелектуалів / Реймон Арон; [пер. $з$ фр. Г. Філіпчук]. - К.: Юніверс, 2006. - $272 \mathrm{c}$.

3. Гаєк Ф. А. фон. Чому я не консерватор / Фрідріх Август фон Гаєк; [пер. з англ. Н. Поліщук] // Консерватизм: [антологія / упоряд. О. Проценко, В. Лісовий]. — К.: Смолоскип, 1998. - 598 c. - С. $65-81$.

4. Манхейм К. Идеология и утопия / Карл Манхейм; [пер. М. И. Левиной] // Диагноз нашего времени / Карл Манхейм. - М.: Юрист, 1994. — 700 с. —С. 7-276.

5. Валлерстайн И. После либерализма / Иммануэль Валлерстайн; [пер. с англ.; под. ред. Б. Ю. Кагарлицкого]. - М.: Едиториал УРСС, 2003.—256 с.

6. Бёрк Э. Размышления о революции во Франции и о прениях в некоторых лондонских обществах касательно сего события, содержащиеся в письме, предполагавшемся быть отправленным некоему благородному господину в Париж / Эдмунд Бёрк; [пер. с англ. С. Векслер; под. ред. А. Бабича; предисл. и замеч. К. К. О’Брайен]. - London: Overseas Publications Interchange Ltd, 1992. — $411 \mathrm{c}$.

7. Берк Е. Конституція на праві давності / Едмунд Берк; [пер. $з$ англ. Н. Філіпенко] // Консерватизм: [антологія / упоряд. О. Проценко, В. Лісовий].-К.: Смолоскип, 1998. - 598 c. - C. 473.

8. Куц Г.М. Трансформаційний потенціал лібералізму в політичному просторі: автореф. дис. на здобуття наук. ступеня докт. політ. наук: спец. 23.00.02 «Політичні інститути та процеси» / Г. М. Куц. — Чернівці: Чернівецький національний університет імені Ю. Федьковича, 2011.-36 c.

9. Куц Г. М. Лібералізм і демократія: перипетії співіснування / Г. М. Куц // Віче. - 2007. — № 12. Спецвипуск.—С. 17-20.

10. Шуттінгер Р. Проблема ідентичності консерватизму / Роберт Шуттінгер; [пер. $з$ англ. В. Лісового] // Консерватизм: [антологія / упоряд. О. Проценко, В. Лісовий].—К.: Смолоскип, 1998. - 598 c. - C. 20-39. 


\section{References}

1. Kettler D. (2000), «Ideolohiya», Entsyklopediya politychnoyi dumky, Dukh i Litera, Kyyiv, 472 p., pp. 141-143.

2. Aron R. (2006), «Opiy intelektualiv», Yunivers, Kyyiv, 272 p.

3. Hayek F. A. fon. (1998), «Chomu ya ne konservator», Smoloskyp, Kyyiv, 598 p., pp. $65-81$.

4. Mankheym K. (1994), «Ydeolohyya y utopyya», Dyahnoz nasheho vremeny, Yuryst, Moskva, 700 p., pp. 7-276.

5. Vallerstayn Y. (2003), «Posle lyberalyzma», Edytoryal URSS, Moskva, 256 p.

6. Bërk É. (1992), «Razmyshlenyya o revolyutsyy vo Frantsyy y o prenyyakh v nekotorykh londonskykh obshchestvakh kasatelno seho sobytyya, soderzhashchyesya v pysme, predpolahavshemsya byt otpravlennym nekoemu blahorodnomu hospodynu v Paryzh», Overseas Publications Interchange Ltd, London, $411 \mathrm{p}$.

7. Berk E. (1998), «Konstytutsiya na pravi davnosti», Konservatyzm: antolohiya, Smoloskyp, Kyyiv, 598 p., pp. 473.

8. Kuts H. M. (2011), «Transformatsiynyy potentsial liberalizmu v politychnomu prostori», avtoref. dys. na zdobuttya nauk. stupenya dokt. polit. nauk, Chernivtsi, $36 \mathrm{p}$.

9. Kuts H. M. (2007), «Liberalizm i demokratiya: perypetiyi spivisnuvannya», Viche, № 12. Spetsvypusk. pp. 17-20.

10. Shuttinher R. (1998), «Problema identychnosti konservatyzmu», Konservatyzm: antolohiya, Smoloskyp, Kyyiv, 598 p., pp. 20-39. 